\title{
Receptor-Binding Specificity Depending on N-terminal Structure of VIP/PACAP
}

\author{
Satomi Onoue 1 , Yumiko Nagano ${ }^{1}$, Ichiro Tatsuno ${ }^{2}$, Daigaku Uchida ${ }^{2}$ and Kazuhisa Kashimoto ${ }^{1}$ \\ ${ }^{1}$ Itoham Foods Inc., Central Research Institute, Kubogaoka, Ibaraki 302-0104, Japan \\ ${ }^{2}$ Second Department of Internal Medicine, Chiba University School of Medicine, Chiba 260-8670, Japan \\ (Received 10 June 1999; and accepted 26 September 1999)
}

\begin{abstract}
Naturally occurring neuro-polypeptide VIP and PACAP 27 are generally categorized into the glucagon-secretin family from their structural similarities and biological activities. They are also known to act as cAMP-inducing factors by activating adenylate cyclase. In the present study, we evaluated the binding ability of native VIP/PACAP and N-terminal modified VIP/ PACAP analogues to specific receptors and their effects on cAMP accumulation, in order to examine if the receptor-selectivity is significantly influenced by $\mathrm{N}$-terminal modification. N-terminal modified VIP, $\left[\mathrm{G}^{4}, \mathrm{I}^{5}\right]$-VIP, gained higher binding potency to the PACAP receptor as compared with native VIP. However, the biological activity of $\mathrm{N}$-terminal modified PACAP, $\left[\mathrm{A}^{4}, \mathrm{~V}^{5}\right]$-PACAP, was lower as compared with native PACAP 27. Since the N-terminal structures of VIP/PACAP seemed to play an important role in their receptorbinding specificity, we synthesized some VIP/PACAP derivatives focussing on their $\mathrm{N}$ terminal moieties that were reported to induce structural distortions. Their solution structures were analyzed by $2 \mathrm{D}-\mathrm{NMR}$ spectroscopy. The results clearly indicated that $\left[\mathrm{G}^{4}, \mathrm{I}^{5}\right]$-VIP has a PACAP-like physical properties and $\left[\mathrm{A}^{4}, \mathrm{~V}^{5}\right]$-PACAP, conversely, a VIP-like properties. In addition, N-terminal residues of VIP/PACAP were essential in their binding to the specific receptors. Correlation between the structures of VIP/PACAP derivatives and their receptor-binding specificities were discussed on the basis of $\log \mathrm{P}$ values and distance geometry calculations.
\end{abstract}

Upon adenylate cyclase stimulatory effect-guided fractionation of the extract of the ovine hypothalamus, a novel neuropeptide named pituitary adenylate cyclase activating polypeptide (PACAP) was isolated (14). There are two forms of PACAP, PACAP 38 and PACAP 27 consisting of 38 and 27 amino acids residues, respectively (15). Further studies showed that PACAP occurred in a variety of tissues including the pituitary (5), lung (23), adrenal (29), testis (25), and gut (8). And that PACAP worked through

Correspondence to: Satomi Onoue, at the above address.

Tel: +81-297-45-6311, Fax: +81-297-45-6353 the PACAP receptors which were classified into three types, PVR 1, 2, and 3. Main signaling mechanisms of PACAP and its receptors involve the activation of adenylate cyclase and phospholipase-C cascades (22).

The vasoactive intestinal peptide (VIP) is a naturally occurring, 28 amino acids peptide with a wide range of biological activities, VIP was firstly isolated from the porcine duodenum and characterized (24). VIP-1 acts through interaction with two subclasses of seven-transmembrane $G$ protein-coupled receptors named VIP-1 and VIP2 receptors (6), or PVR-2 and-3, respectively. The biological activities of VIP are quite similar to those of PACAP, $e . g$., activities as a potent 
vasodepressor or vasodilator in the cardiovascular system (16) and bronchodilator in the human lung (13). VIP (1; Fig. 1) causes relaxation of smooth muscle cells via both the VIPspecific receptor coupled to nitric oxide synthase and the VIP-preferring receptor coupled to adenylate cyclase (17).

VIP (1) and PACAP 27 (2; Fig. 1) also showed a higher affinity to the PACAP/VIP type 2 receptor (PVR 2). A peptide histidine methionine (PHM), helodermin, and helospectin were selective to the PACAP/VIP type 3 receptor (PVR 3). Two homologous peptides VIP and PACAP 27 therefore share the activity and receptor, and they play an important role in the control of the hypothalamo-pituitary-adrenal (HPA) axis (19). These almost exclusively act in a paracrine manner, since their blood concentrations are very low. Such similar biological activities of VIP and PACAP 27 are presumably derived from their structural similarity, $68 \%$ homology in amino acid sequence. Not only amino acid sequence but solution structures of VIP/PACAP are also relatively similar to each other. VIP has a long term $\alpha$-helix moiety, and helix-forming ability of which depends on $\mathrm{pH}$ and the polarity of solution. In $50 \%$ methanol, a regular, well-defined $\alpha$-helix is formed at residues $10-25$; in $25 \%$ methanol, residues $9-14$ formed an $\alpha$-helix and residues $22-26$, an irregular helix as revealed by NMR data (2). In $50 \%$ trifluoroethanol, PACAP 27 has an $\alpha$-helix formed at residues $9-25$ (31, 18), and other fragments than residues $9-25$ in $\mathrm{N} / \mathrm{C}$-terminals are defined as disordered domains. So VIP/PACAP consist of three domains, i. e., the N-terminal disordered moiety, $\alpha$-helix of a similar length, and the short $\mathrm{C}$ terminal moiety with unsettled form. Judging from both solution structures described above and their sequences, the specificity of binding to their receptors seemed to be dependent on the structure of the $\mathrm{N}$-terminal moiety. There are three different amino acid residues in this moiety between VIP and PACAP. To investigate the N-terminal structure-activity relationship, we prepared VIP/PACAP derivatives with fourth and fifth residues replaced with different amino acids, i. e., [Gly $\left.{ }^{4}, \mathrm{Ile}^{5}\right]$-VIP (3 Fig. 1) and $\left[\mathrm{Ala}^{4}, \mathrm{Val}^{5}\right]$ PACAP 27 (4 Fig. 1; Fig. 1). These peptides were subjected to the cAMP accumulation test and binding assay using Chinese hamster ovary cells stably expressing a PAC 1 short form receptor (PVR 1-CHO).

For further investigation into the effects of the N-terminal moiety on physical properties, we synthesized another four VIP/PACAP derivatives, VIP (1-10) $\mathrm{NH}_{2}$ (5), PACAP (1-10) $\mathrm{NH}_{2}$ (6), $\quad\left[\mathrm{Gly}^{4}, \quad \mathrm{Ile}^{5}\right]$-VIP $(1-10) \mathrm{NH}_{2}$ (7), and [Ala $\left.{ }^{4}, \mathrm{Val}^{5}\right]$-PACAP $(1-10) \mathrm{NH}_{2}(8)$. Physical properties, i. e., $\log \mathrm{P}$, solution structures deduced by CD, 2 D-NMR, and distance geometry calculation of these peptides were examined.

\section{MATERIALS AND METHODS}

\section{Synthesis of peptides}

VIP/PACAP derivatives (1-8, Fig. 1) were synthesized by a manual solid-phase method. p-Methylbenzhydrylamine (MBHA) resin was used as a starting material and the following side-chain protected Boc-amino acids were used for syntheses of peptides: Asn (Xan), Asp

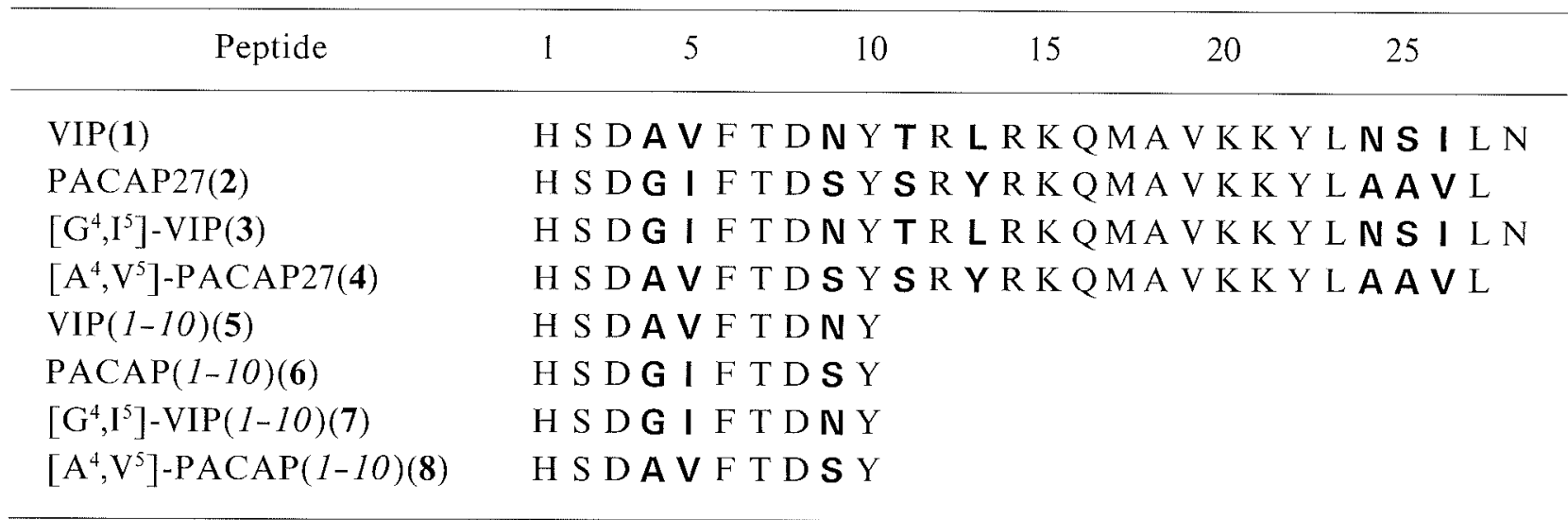

Fig. 1 Amino acid sequences of synthetic peptides. Bold letters represent the different residues in VIP/ PACAP. All peptides were amidated. 
(OcHex), Arg (Tos), Gln (Xan), Lys (Cl-Z), Ser (Bzl), Thr (Bzl), Tyr $\left(\mathrm{Cl}_{2} \mathrm{Bzl}\right)$, and $\mathrm{His}$ (Bom). After construction of each peptide, the protected resin was treated with $\mathrm{HF}$ in order to deblock and cleave the peptide from the resin. The crude peptide was extracted with $50 \%$ acetic acid and was subjected to repeated column chromatography over Chromatorex ODS (Fuji Silysia Chemical Ltd., Aichi, Japan), or preparative RP-HPLC with the $\mathrm{CH}_{3} \mathrm{CN}-\mathrm{H}_{2} \mathrm{O}$ mobile phase system. Purities (>98\%) of the synthetic peptides were checked by reversed phase HPLC, atmospheric pressure chemical ionization mass spectrometry (APCI-MS) and amino acid analyses.

\section{Spectroscopy}

The Circular dichroism (CD) spectra (JASCO720, Japan Spectroscopic Co. Ltd., Tokyo, Japan) were measured at wavelengths from 190 to $260 \mathrm{~nm}$ using an $1 \mathrm{~mm}$ cell. The baseline was corrected with a blank cell. A phosphate buffer $(\mathrm{pH} 7.0)$ and $50 \%(\mathrm{~V} / \mathrm{V})$ aqueous solution of methanol were used as solvents. Peptide concentrations were determined by measuring absorbance at 275 nm (UV-3,100, Shimadzu, Tokyo, Japan); the absorption coefficient was $\varepsilon=1,200$ at $275 \mathrm{~nm}$ for Tyr in an aqueous solution of a peptide.

\section{NMR Spectroscopy}

All NMR experiments were performed on a JEOL $\alpha-500$ spectrometer operating at $500 \mathrm{MHz}$ for observation of protons. All samples $(60 \mathrm{mg} / \mathrm{mL})$ dissolved in dimethyl sulfoxide (DMSO) $-\mathrm{d}_{6}$ $(99.8 \%$ D, Merck, Darmstadt, Germany) were maintained at $40^{\circ} \mathrm{C}$. Connectivities between the amide protons and their $\mathrm{H} \alpha$ protons seen in "finger-print" regions were established by double quantum-filtered correlated spectroscopy (DQFCOSY). Heteronuclear Shift Correlation (HETCOR) and Homonuclear Hartmann-Hahn spectroscopy (HOHAHA) were also measured if necessary. Nuclear Overhauser enhancement (NOE) experiments were conducted with mixing times of 0.2 and $0.3 \mathrm{~s}$ in two dimensions; values taken from the $0.2 \mathrm{~s}$ experiments were used for assessments. The dihedral angle $\phi$ between $\mathrm{NH}$ and $\mathrm{C} \alpha \mathrm{H}$ was calculated from ${ }^{3} J_{\mathrm{HN}_{\alpha}}$ coupling constants using the Karplus relationship as follows (11):

$$
{ }^{3} J=\mathrm{A} \cos ^{2} \theta+\mathrm{B} \cos \theta+\mathrm{C}(\mathrm{I})
$$

The coefficients $A, B$, and $C$ in the equation $I$ were variable depending on specific bonds and the parameters of Pardi et al. (21) were applied to the equation $\mathrm{I}, i$. e., vicinal coupling constants ${ }^{3} J_{\mathrm{HN} \alpha}, \mathrm{A}=6.4, \mathrm{~B}=-1.4, \mathrm{C}=1.9$, and $\theta=$ $\phi-60^{\circ}$.

To resolve the Karplus equation, we took advantage of a calculator program; SWEET J (1). Data obtained were treated as structural information to refine solution structures in distance geometry calculation.

The properties of synthesized compounds are as follows:

VIP (1-10) $\mathrm{NH}_{2}$ (5 Fig. 1): white amorphous powder, $[\alpha]_{\mathrm{D}}-33.8^{\circ}(c=0.5, \mathrm{MeOH}), \mathrm{UV} \lambda_{\max }$ $(\mathrm{MeOH}) \mathrm{nm}(\log \varepsilon): 275$ (4.31), CD $(50 \% \mathrm{MeOH}$ phosphate buffer, $\mathrm{pH}$ 7.0) $\Delta \varepsilon(\mathrm{nm}):-2.10$ (203), -0.59 (230), APCI-MS m/z: $1168[\mathrm{M}+\mathrm{H}]^{+},{ }^{1} \mathrm{H}-\mathrm{NMR}\left(500 \mathrm{MHz}, \mathrm{DMSO}-\mathrm{d}_{6}\right)$ : Each chemical shift assignment is performed as shown in Table 1.

PACAP (1-10) $\mathrm{NH}_{2}$ (6): white amorphous powder, $[\alpha]_{\mathrm{D}}-19.0^{\circ}(c=0.5, \mathrm{MeOH}), \mathrm{UV} \lambda_{\max }$ $(\mathrm{MeOH}) \mathrm{nm}(\log \varepsilon): 275(4.35), \mathrm{CD}(50 \% \mathrm{MeOH}$ phosphate buffer, $\mathrm{pH}$ 7.0) $\Delta \varepsilon(\mathrm{nm}):-1.44$ (203), -0.35 (230), APCI-MS m/z: $1141[\mathrm{M}+\mathrm{H}]^{+},{ }^{1} \mathrm{H}-\mathrm{NMR}\left(500 \mathrm{MHz}, \mathrm{DMSO}-\mathrm{d}_{6}\right)$ : (Table 1)

$\left[\mathrm{G}^{4}, \mathrm{I}^{5}\right]$-VIP (1-10) $\mathrm{NH}_{2}$ (7): white amorphous powder, $[\alpha]_{\mathrm{D}}-62.8^{\circ}(c=0.5, \mathrm{MeOH}), \mathrm{UV} \lambda_{\text {max }}$ $(\mathrm{MeOH}) \mathrm{nm}(\log \varepsilon): 275$ (4.33), $\mathrm{CD}(50 \% \mathrm{MeOH}$ phosphate buffer, $\mathrm{pH}$ 7.0) $\Delta \varepsilon(\mathrm{nm}):-1.58$ (202), -0.44 (230), APCI-MS $\mathrm{m} / \mathrm{z}$ : $1168[\mathrm{M}+\mathrm{H}]^{+},{ }^{1} \mathrm{H}-\mathrm{NMR}\left(500 \mathrm{MHz}, \mathrm{DMSO}-\mathrm{d}_{6}\right)$ : (Table 1)

$\left[\mathrm{A}^{4}, \mathrm{~V}^{5}\right]$-PACAP $(1-10) \mathrm{NH}_{2}(\mathbf{8})$ : white amorphous powder, $[\alpha]_{\mathrm{D}}-37.2^{\circ}(c=0.5, \mathrm{MeOH})$, UV $\lambda_{\max }(\mathrm{MeOH}) \mathrm{nm}\left(\log _{\varepsilon}\right): 275$ (4.35), CD $(50 \% \mathrm{MeOH}$ phosphate buffer, pH 7.0) $\Delta \varepsilon(\mathrm{nm}):-2.01$ (203), -0.46 (231), APCI-MS m/ z: $1141[\mathrm{M}+\mathrm{H}]^{+},{ }^{1} \mathrm{H}-\mathrm{NMR}(500 \mathrm{MHz}$, DMSO$\left.\mathrm{d}_{6}\right)$ : (Table 1)

\section{$\log P$}

The general procedure of Stefan H. Unger (28) was used to estimate the $n$-octanol/water partition coefficient, $\log \mathrm{P}$, which shows the lipophilic or hydrophobic properties of compounds.

The $\log \mathrm{P}$ values of standard compounds for the standard regression line were determined by 
Table $1{ }^{\prime} H$ assignment and chemical shift data for VIP/PACAP derivatives (5-8) in DMSO-d at $313 \mathrm{~K}$. All chemical shifts are given as o (ppm) values referring to tetramethylsilane as the internal standard.

\begin{tabular}{|c|c|c|c|c|c|c|c|c|c|}
\hline \multirow{2}{*}{ Residue } & \multicolumn{4}{|c|}{ Chemical shift (ppm) } & \multirow[t]{2}{*}{ Residue } & \multicolumn{4}{|c|}{ Chemical shift (ppm) } \\
\hline & $\mathrm{NH}$ & $\alpha \mathrm{CH}$ & $\beta \mathrm{CH}$ & Others & & $\mathrm{NH}$ & $\alpha \mathrm{CH}$ & $\beta \mathrm{CH}$ & Others \\
\hline \multicolumn{5}{|c|}{ VIP $(1-10) \mathrm{NH}_{2}(5)$} & \multicolumn{5}{|c|}{ PACAP $(1-10) \mathrm{NH}_{2}(6)$} \\
\hline His 1 & -- & 4.22 & 3.20 & $8.80,7.39$ & His 1 & -- & 4.22 & 3.22 & $8.86,7.42$ \\
\hline Ser 2 & 8.68 & 4.40 & $3.69 / 3.63$ & & Ser 2 & 8.69 & 4.42 & $3.74 / 3.66$ & \\
\hline Asp 3 & 8.58 & 4.66 & $2.73 / 2.56$ & & Asp 3 & 8.59 & 4.62 & $2.75 / 2.59$ & \\
\hline Ala 4 & 7.82 & 4.29 & 1.14 & & Gly 4 & 7.95 & 3.72 & & \\
\hline Val 5 & 7.63 & 4.09 & 1.91 & $0.75 / 0.73$ & Ile 5 & 7.69 & 4.18 & 1.67 & $1.31 / 0.99,0.76 / 0.75$ \\
\hline Phe 6 & 8.06 & 4.66 & $3.07 / 2.82$ & $7.24,7.15$ & Phe 6 & 8.12 & 4.62 & $3.07 / 2.83$ & $7.24,7.16$ \\
\hline Thr 7 & 7.83 & 4.26 & 4.01 & 1.04 & Thr 7 & 7.80 & 4.24 & 4.00 & 1.04 \\
\hline Asp 8 & 8.12 & 4.58 & $2.73 / 2.56$ & & Asp 8 & 8.12 & 4.62 & $2.75 / 2.59$ & \\
\hline Asn 9 & 7.97 & 4.47 & $2.56 / 2.38$ & $7.33 / 6.87$ & Ser 9 & 7.75 & 4.23 & $3.57 / 3.48$ & \\
\hline Tyr 10 & 7.73 & 4.26 & $2.93 / 2.79$ & $6.94,6.65$ & Tyr 10 & 7.83 & 4.41 & $2.95 / 2.77$ & $7.02,6.65$ \\
\hline \multicolumn{5}{|c|}{$\left[\mathrm{G}^{4}, \mathrm{I}^{5}\right]-\mathrm{VIP}(1-10) \mathrm{NH}_{2}(7)$} & \multicolumn{5}{|c|}{$\left[\mathrm{A}^{4}, \mathrm{~V}^{5}\right]$-PACAP $(1-10) \mathrm{NH}_{2}(8)$} \\
\hline His 1 & -- & 4.22 & 3.21 & $8.81,7.40$ & His 1 & -- & 4.20 & 3.21 & $8.83,7.40$ \\
\hline Ser 2 & 8.69 & 4.41 & $3.69 / 3.63$ & & Ser 2 & 8.68 & 4.41 & $3.71 / 3.63$ & \\
\hline Asp 3 & 8.60 & 4.65 & $2.73 / 2.59$ & & Asp 3 & 8.58 & 4.68 & $2.73 / 2.56$ & \\
\hline Gly 4 & 7.95 & 3.71 & & & Ala 4 & 7.83 & 4.32 & 1.14 & \\
\hline Ile 5 & 7.69 & 4.18 & 1.37 & $1.29 / 0.98,0.76 / 0.74$ & Val 5 & 7.64 & 4.10 & 1.91 & $0.76 / 0.74$ \\
\hline Phe 6 & 8.12 & 4.65 & $3.07 / 2.83$ & $7.24,7.16$ & Phe 6 & 7.99 & 4.65 & $3.07 / 2.82$ & $7.24,7.16$ \\
\hline Thr 7 & 7.79 & 4.25 & 4.01 & 1.04 & Thr 7 & 7.85 & 4.24 & 3.99 & 1.04 \\
\hline Asp 8 & 8.12 & 4.58 & $2.73 / 2.59$ & & Asp 8 & 8.12 & 4.63 & $2.73 / 2.56$ & \\
\hline Asn 9 & 7.97 & 4.48 & $2.56 / 2.38$ & $7.34 / 6.88$ & Ser 9 & 7.75 & 4.23 & $3.57 / 3.48$ & \\
\hline Tyr 10 & 7.73 & 4.26 & $2.93 / 2.74$ & $6.99,6.66$ & Tyr 10 & 7.82 & 4.30 & $2.95 / 2.76$ & $7.01,6.65$ \\
\hline
\end{tabular}

the shake-flask method (3). In this classical procedure using flasks, we used octanol saturated with $0.1 \%$ trifluoroacetic acid (TFA) aqueous solution and $0.1 \%$ TFA aqueous solution saturated with n-octanol. We used $20 \% \mathrm{CH}_{3} \mathrm{CN}$ in $0.1 \%$ TFA aqueous solution as mobile phase in HPLC system, and formamide as a suitable nonretained compound to define the dead volume $\left(\mathrm{t}_{0}\right)$.

\section{Calculations}

The structures of peptides were calculated using DISTGEOM in the TINKER program package (9) with distance constraints which depend on data from NOESY spectra. The distance restrains were interpreted in a conservative manner by setting the upper bound distance between the two dipolar-coupled protons to $5.0 \AA$ and the lower bound distance to $1.86 \AA$.

In this program, molecules were initially refined by brief minimization of penalty function, and then simulated annealing method was applied continuously. The penalty function: amber force field for the molecular mechanics calculations consisted of a series of atom-based energy terms to enforce local bond geometry.

The structures were equilibrated at $200^{\circ} \mathrm{C}$ for 1,000 steps of molecular dynamics (time-step: 0.04 ps), followed by 10,000 dynamics steps of cooling to $0^{\circ} \mathrm{C}$ (time-step: $0.02 \mathrm{ps}$ ).

\section{CHO Cells Stably Expressing PACAP/VIP Receptors}

$\mathrm{CHO}$ cells were transfected with pSV 2 neo expression plasmids carring full-length cDNA encoding PACAP/VIP specific receptors such as rat PVR 1, PVR 2, and PVR 3 (27). Stable transformants were selected in a minimal essential medium containing $10 \%$ fetal calf serum (Hyclone) and G 418 at $400 \mu \mathrm{g} / \mathrm{mL}$.

\section{Binding Assay}

The binding assay was generally performed as previously described $(26,27)$.

CHO cells were scraped mechanically from culture dishes using a rubber policeman. Cells 
were resuspended in an ice-cold membrane buffer; $50 \mathrm{mM}$ Tris buffer (pH 7.4), $5 \mathrm{mM} \mathrm{MgCl}_{2}, 0.5$ $\mathrm{mg} / \mathrm{mL}$ bacitracin, $0.5 \mathrm{mM}$-amidinophenyl methanesulfonyl fluoride hydrochloride ( $p$ APMSF), and a protease inhibitor cocktail (10 $\mu \mathrm{g} / \mathrm{mL}$ pepstain $\mathrm{A}, 10 \mu \mathrm{g} / \mathrm{mL}$ antipain, $10 \mu \mathrm{g} /$ $\mathrm{mL}$ chymostatin, $10 \mu \mathrm{g} / \mathrm{mL}$ leupeptin). The homogenate of the cells was centrifuged at $250 \times$ $g$ for $10 \mathrm{~min}$ to collect the supernatant, and the membrane fraction was prepared by ultracentrifugation of the supernatant $(50,000 \mathrm{~g} \times$ $30 \mathrm{~min}$, twice). The binding assay was performed in a total volume of $300 \mu \mathrm{L}$ of the membrane buffer containing $1 \%$ BSA (binding buffer) at $22^{\circ} \mathrm{C}$. $\left[{ }^{125} \mathrm{I}\right]$-PACAP 27 membrane preparations and various concentrations of peptides were incubated. The assay was terminated by rapid filtration through Whatman GF/B glass paper filters, which were presoaked in $0.5 \%$ polyethylenimine using a cell harvester (Brandel Biomedical Research \& Development Laboratories, Gaithersburg, MD). Each filter was counted for radioactivity by an automatic gamma counter.

\section{c AMP Accumulation}

Extracellular cAMP was measured by radioimmunoassay (RIA) after incubation at $37^{\circ} \mathrm{C}$ with various concentrations of peptides and DMEM containing $0.1 \% \mathrm{BSA}$ in an atomosphere of $95 \%$ air and $5 \% \mathrm{CO}_{2}$. A commercial kit provided by Yamasa Corporation (Chyoshi, Japan) was used for RIA.

\section{RESULTS}

Binding Assay and $c$ AMP Accumulation

The binding potency of VIP/PACAP to each receptors is shown in Fig. 2. PACAP 27;Fig. 2 (2) showed high affinity to PVR 1, 2, and 3 as previously reported (20). VIP (1) showed similar affinity to PVR 2 and 3, but the affinity to PVR 1 was very low. To evaluate the obvious difference of binding ability between VIP/PACAP derivatives, $\mathrm{CHO}$ cells stably expressing PAC 1 (PVR 1-CHO) showing high specificity to PACAP were used in further investigation of binding study at each peptides (Fig. 3).

Although VIP (1) could not displace $\left[{ }^{125} \mathrm{I}\right]$ PACAP bound to the receptor at lower concentrations, PACAP 27 (2) could do it in a dosedependent fashion. The Scatchard analysis of the displacement of $\left[{ }^{125}\right.$ I] -PACAP 27 binding indicated the existence of a single class of binding sites. Dissociation constants (Kd) were calculated to be $0.18 \mathrm{nM}$ for PACAP 27 (2), $3.84 \mathrm{nM}$ for $\left[\mathrm{Ala}^{4}, \mathrm{Val}^{5}\right]$-PACAP 27 (4), $48.5 \mathrm{nM}$ for $\left[\mathrm{Gly}^{4}, \mathrm{Ile}^{5}\right]$-VIP (3), and over $1,000 \mathrm{nM}$ for VIP (1).

While native VIP (1) has a very low affinity to PVR 1, the Kd constant of $\mathrm{N}$-terminal replaced analogue $\left[\mathrm{Gly}^{4}, \mathrm{Ile}^{5}\right]$-VIP (3) was considerably decreased. Still the Kd was more than 100-fold larger than that of PACAP (2). By contrast,
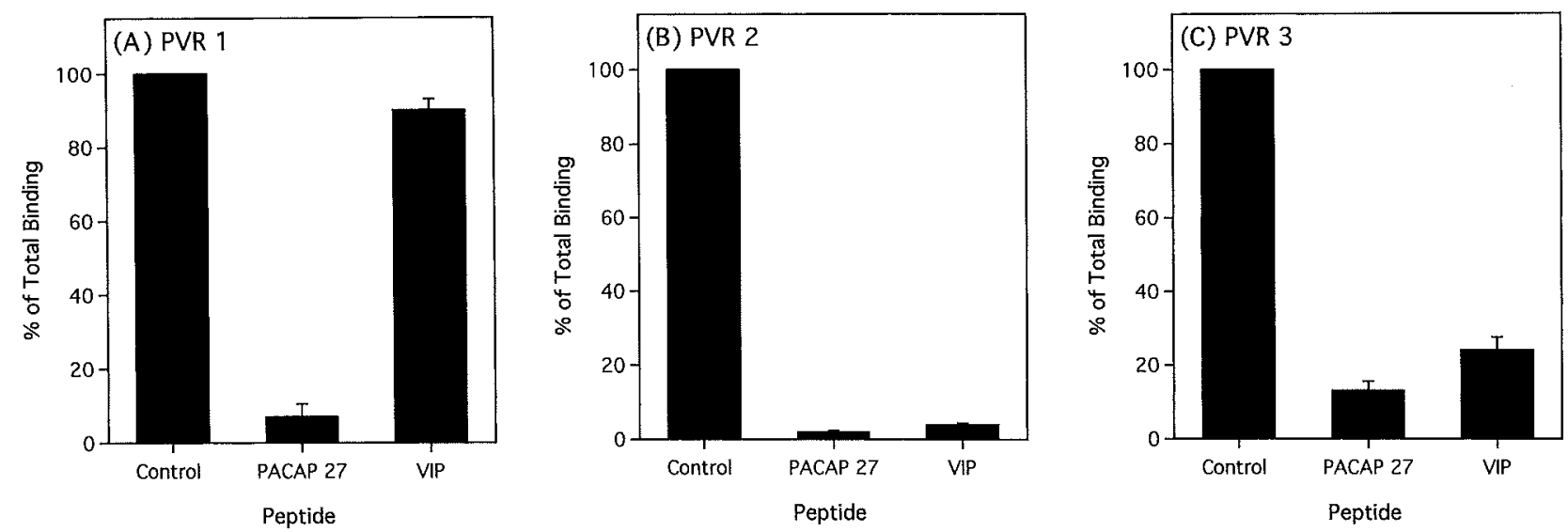

Fig. 2 Competition between $\left[{ }^{125} \mathrm{I}\right]$-PACAP and VIP/PACAP. The control (100\%) shows counts obtained with $\left[{ }^{125} I\right]-P A C A P$ without a competitor. Means with standard deviations are shown. Cells expressing PVR 1 (alternatively called as PACAP type I), expressing PVR 2 (VIP type I), and expressing PVR 3 (VIP type II) were incubated with $\left[{ }^{125} \mathrm{I}\right]-\mathrm{PACAP}$ in the presence of $100 \mathrm{nM}$ unlabeled peptides and the results are shown in $\mathrm{A}, \mathrm{B}$, and $\mathrm{C}$, respectively. 


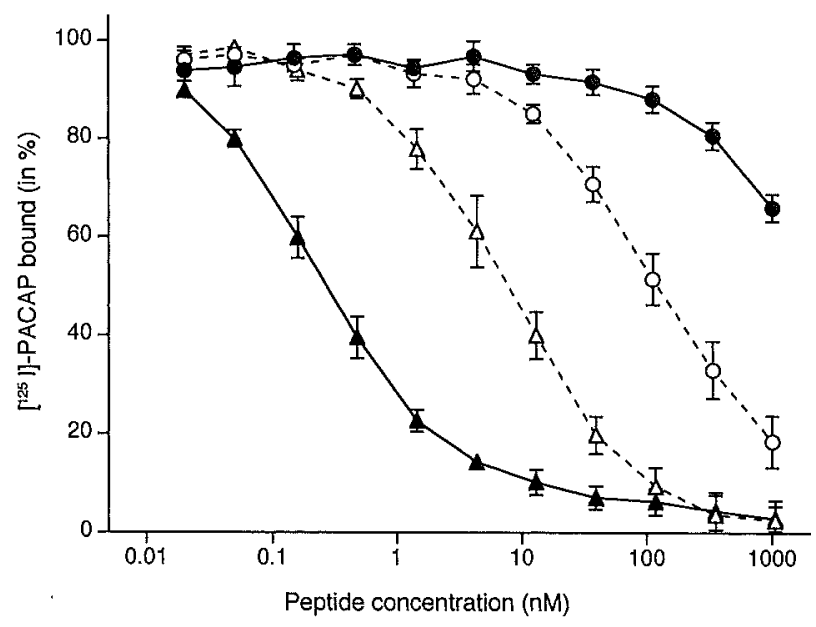

Fig. 3 Dose-effect curves for inhibition of $\left[{ }^{125} \mathrm{I}\right]-$ PACAP binding to membranes on $\mathrm{CHO}$ cells expressing PVR 1 in the presence of VIP $(-\operatorname{PACAP}(\boldsymbol{\Lambda})$, $\left[\mathrm{G}^{4}, \mathrm{I}^{5}\right]$-VIP $(O)$, and $\left[\mathrm{A}^{4}, \mathrm{~V}^{5}\right]$-PACAP $(\triangle)$. Binding data are expressed as a percentage of radioligand specifically bound in the absence of unlabelled peptides. Each point with a bar represents the mean $\pm S D(n=3)$.

another analogues $\left[\mathrm{Ala}^{4}, \mathrm{Val}^{5}\right]$-PACAP (4) showed the increment of $\mathrm{Kd}$ by more than 10 -fold as compared with that of native PACAP (2) (Fig. $3)$.

We also determined concentrations of $\mathrm{CAMP}$ in PVR 1-CHO, PVR 2-CHO, and PVR 3-CHO cells treated with a variety of peptides (Fig. 4). The results in this experiment showed high congruence with a series of data obtained by competitive binding experiments (Fig. 3).

Except for PVR 3, each receptor showed ligand-selectivity, i.e., PVR 1 for PACAP (2) and PVR 2 for VIP (1). Modified VIP/PACAP derivatives $(3,4)$ showed alterations in binding specificities. That is, modified VIP (3) gained higher affinity to the receptor as compared with the native compound (1), and modified PACAP (4) showed conversely lower affinity as compared with PACAP 27 (2).

\section{$C D$ Spectroscopy}

The CD spectra of the native compounds 1,2 and their partially substituted derivatives $\mathbf{3}, \mathbf{4}$ were obtained at two hydrophilic environments under the same $\mathrm{pH}$ and temparature (Fig. 5). The secondary structure prediction was performed according to Greenfield \& Fasman (1969) (7). As previ-
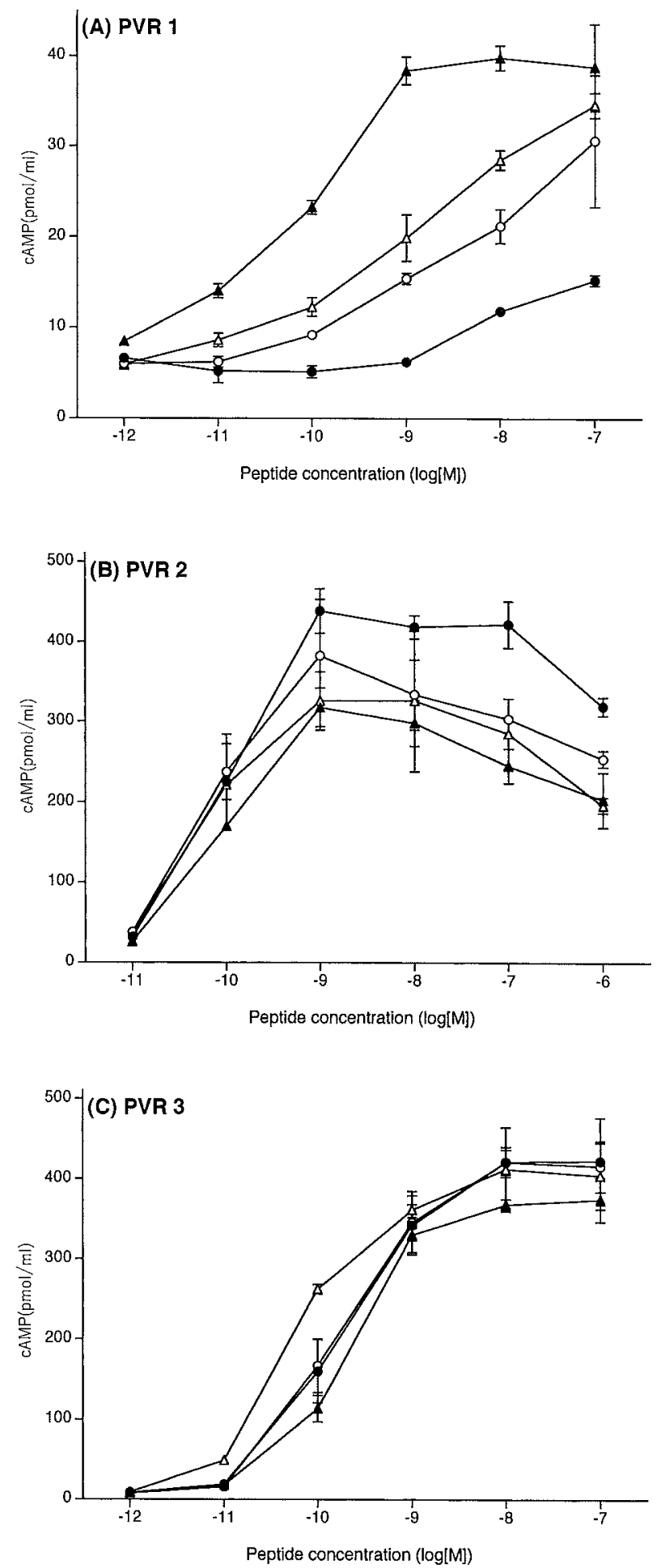

Fig. 4 Accumulation of cAMP in CHO cells transfected with plasmids harboring PACAP/VIP receptors. Concentrations of CAMP were measured after stimulation with VIP $(\mathbf{O}), \operatorname{PACAP}(\boldsymbol{\Delta}),\left[\mathrm{G}^{4}, \mathrm{I}^{5}\right]$-VIP $(\mathrm{O})$, and $\left[\mathrm{A}^{4}, \mathrm{~V}^{5}\right]$-PACAP $(\triangle)$. A, PVR 1-CHO; B, PVR 2-CHO; and C, PVR 3. Each point with a bar represents the mean $\pm S D(n=3)$. 


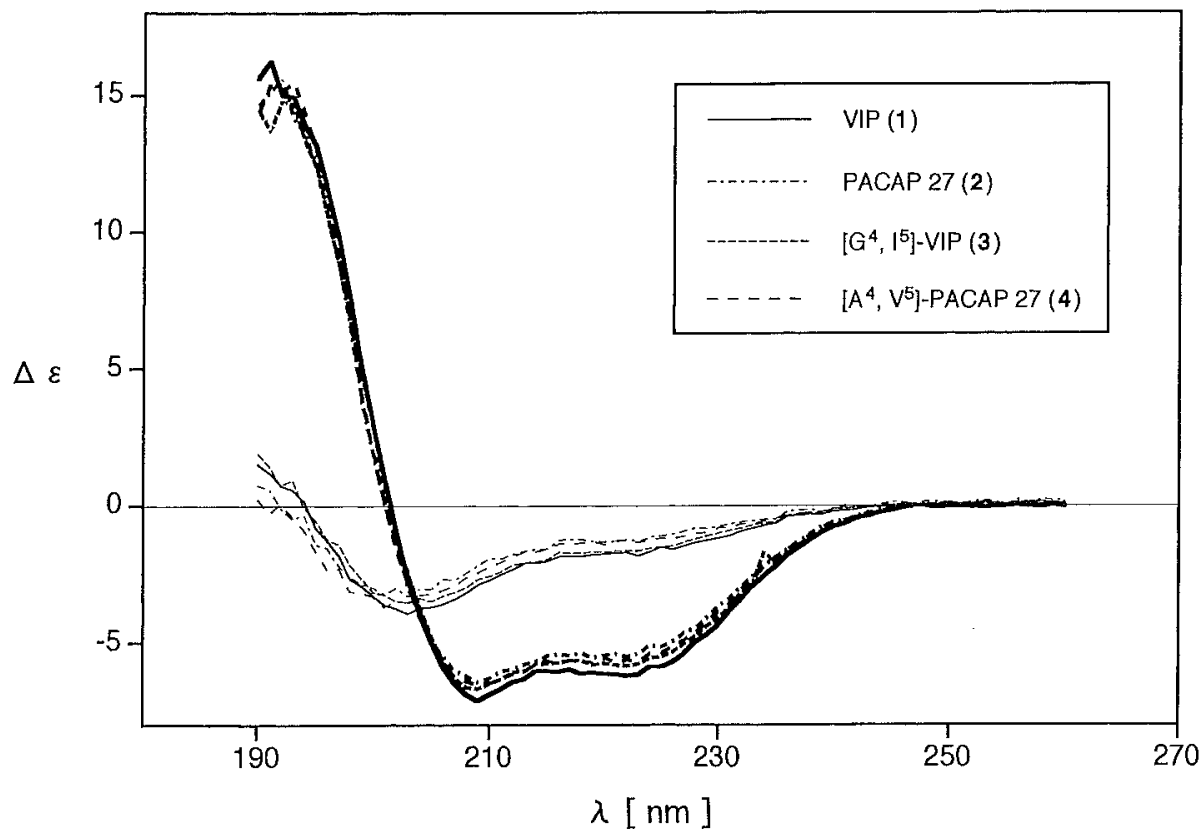

Fig. 5 CD spectra of VIP/PACAP derivatives (1-4). The spectra of bold line were measured in $50 \%(\mathrm{~V} / \mathrm{V})$ methanol/phosphate buffer. The spectra of thin lines were measured in a phosphate buffer $(\mathrm{pH} 7.0)$.

ously reported (10), highly helical contents were indicated under the presence of $50 \% \mathrm{MeOH}$. Almost the same helical contents were predicted in VIP/PACAP and their analogues under both conditions (Table 2).

In CD spectra measured in a phosphate buffer ( $\mathrm{pH} 7.0$ ), comparatively similar contents of helical structures were shown. N-terminal partial substitution therefore caused no significant changes in the long helical moiety formed in the middle domain.

\section{NMR spectral Study and Calculations}

All signals observed in ${ }^{1} \mathrm{H}-\mathrm{NMR}$ were assigned by the analyses of DQF-COSY, HOHAHA, HETCOR, and NOESY spectra based on the methods pioneered by Wüthrich and co-workers $(30,32)$.

Firstly we identified each proton of the same residue by tracing connectivity patterns in COSY and HOHAHA spectra (Fig. 6). Then we classified each residue on the basis of these signal patterns and by comparison with chemical shifts derived from model peptides.

We took advantage of NOEs in backbone protons obtained from NOESY spectra to find which residues were likely neighbors. Thereby we could specifically identify the sequential number of each residue.

In the amide proton region, many doublet proton signals were observed with $\mathrm{H}-2$ of the imidazol ring of $\mathrm{His}^{1}$, which could be discriminated from the other protons by its coupling pattern and by cross-peaks in HETCOR. In the finger-

Table 2 CD spectra and helical structure content of VIP/PACAP derivatives. a, Concentration of each sample $=c a .1 \mathrm{mM}$ in a phosphate buffer $(\mathrm{pH} \mathrm{7.0)}$ and $50 \%(\mathrm{~V} / \mathrm{V})$ methanol phosphate buffer. $b, \mathrm{Mol}$ ellipticity at $208 \mathrm{~nm}$. c, Calculated according to Greenfield \& Fasman (1969).

\begin{tabular}{cccccc}
\hline & \multicolumn{2}{c}{ phosphate buffer } & & \multicolumn{2}{c}{$50 \%(\mathrm{~V} / \mathrm{V}) \mathrm{MeOH}$ phosphate buffer } \\
\cline { 2 - 3 } peptide $^{\mathrm{a}}$ & {$[\theta]_{208}{ }^{\mathrm{b}}$} & helix contents $(\%)^{\mathrm{c}}$ & & {$[\theta]_{208}{ }^{\mathrm{b}}$} & helix contents $(\%)^{\mathrm{c}}$ \\
\hline VIP (1) & $-10,492$ & 22.4 & & $-22,608$ & 64.2 \\
PACAP 27 (2) & $-8,147$ & 14.3 & & $-20,477$ & 56.8 \\
{$\left[\mathrm{G}^{4}, \mathrm{I}^{5}\right]$-VIP (3) } & $-9,863$ & 20.2 & & $-21,868$ & 61.6 \\
{$\left[\mathrm{~A}^{4}, \mathrm{~V}^{5}\right]^{-P A C A P ~ 27}(\mathbf{4})$} & $-8,664$ & 16.1 & & $-21,105$ & 59.0 \\
\hline
\end{tabular}



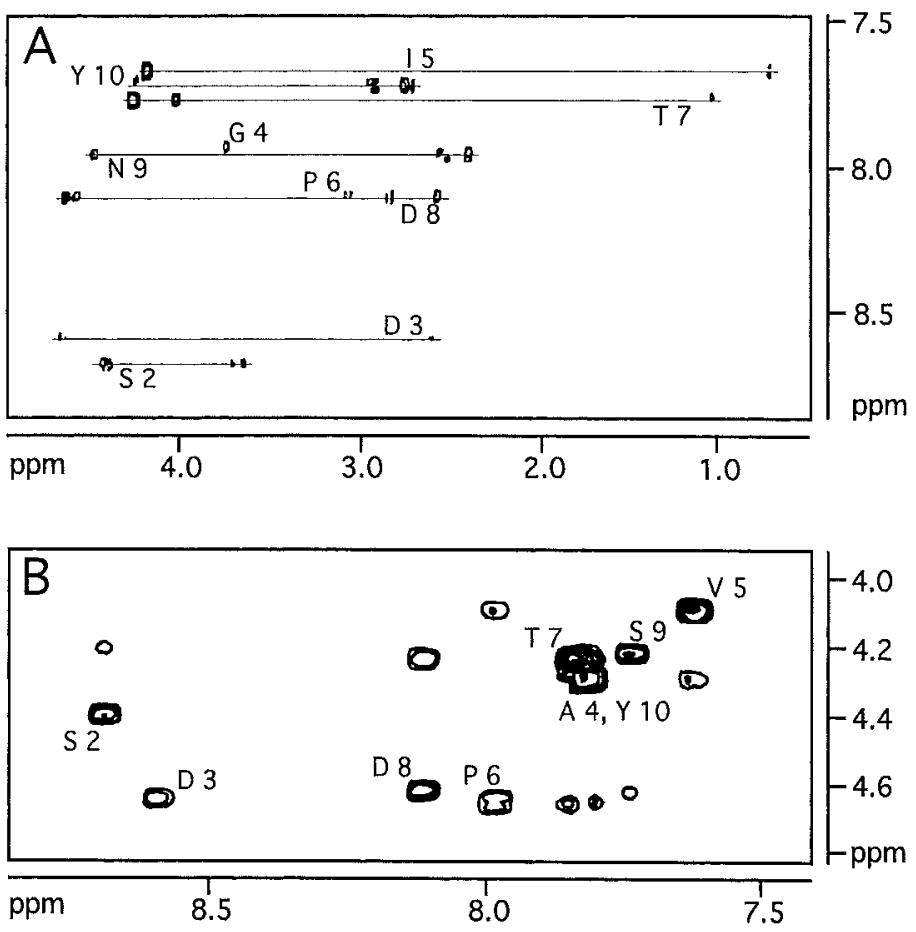

Fig. 6 A two-dimensional NMR HOHAHA (A) and COSY (B) spectrum. A, HOHAHA spectrum of $\left[\mathrm{G}^{4}, \mathrm{I}^{5}\right]$-VIP $(1-10) \mathrm{NH}_{2}$ (7) showing scalar connectivities. B, Combined plot of the "fingerprint" regions of COSY spectrum for $\left[\mathrm{A}^{4}, \mathrm{~V}^{5}\right]$-PACAP $(1-10) \mathrm{NH}_{2}(8)$.
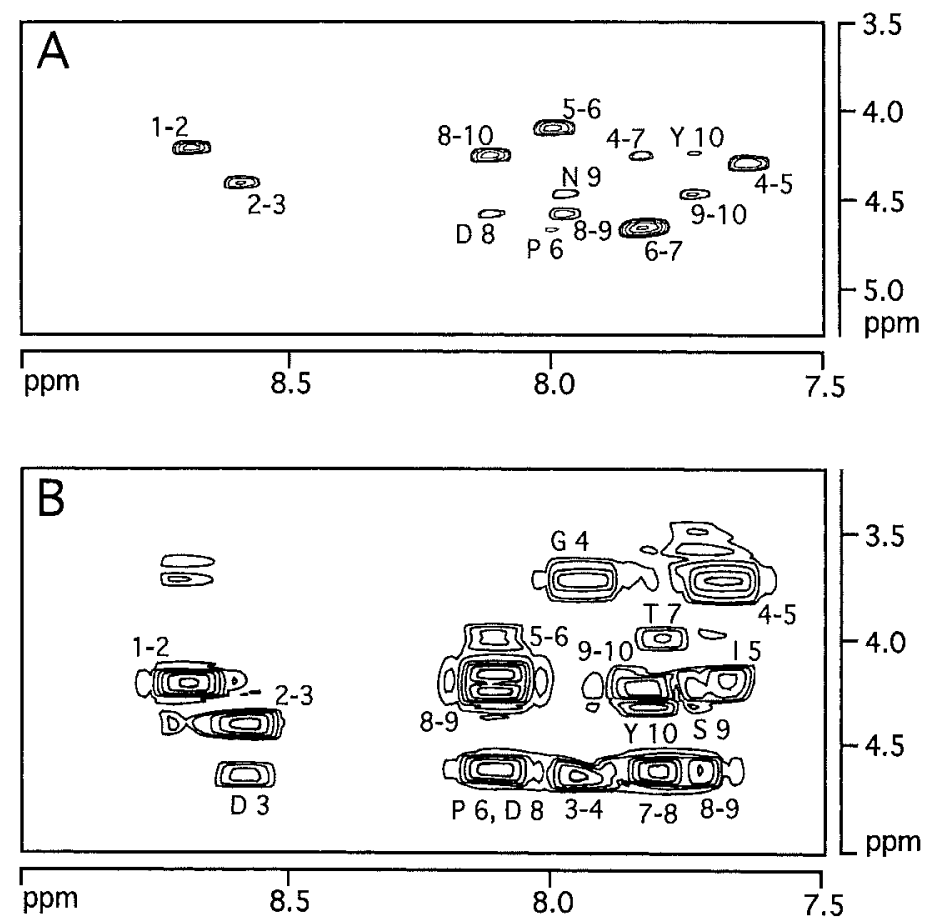

Fig. 7 A fingerprint region $\left(\mathrm{NH}-\mathrm{CH}_{\alpha}\right.$ ) of the two-dimensional NMR NOESY spectrum of A: VIP (110) $\mathrm{NH}_{2}$ (5) and B: PACAP $(1-10) \mathrm{NH}_{2}(6)$. The dipolar through-space connectivities are shown. The mixing time was $0.3 \mathrm{~s}$. 
print region $\left(\mathrm{NH}-\mathrm{CH}_{\alpha}\right)$ of the two-dimensional NMR NOESY, many dipolar through-space connectivities of each peptide were confirmed (Fig. 7). This observed correlation was also available for prediction of secondary structures, i.e., helical regions were identified by a continuous stretch of $\mathrm{NH}$ (i)- $\mathrm{NH}(\mathrm{i}+1)$, the presence of $\mathrm{C}_{\alpha} \mathrm{H}$ (i)- $\mathrm{NH}$ $(\mathrm{i}+3)$, and $\mathrm{C}_{\alpha} \mathrm{H}(\mathrm{i})-\mathrm{C}_{\beta} \mathrm{H}(\mathrm{i}+3)$ NOEs. In the present study, there was no evidence of helical structures in VIP (1-10) $\mathrm{NH}_{2}$ (5) and other derivatives (6-8). But aromatic interactions between the imidazole ring of $\mathrm{His}^{1}$ and the aryl group of $\mathrm{Phe}^{6}$, and between those of $\mathrm{Phe}^{6}$ and $\mathrm{Tyr}^{10}$ in VIP $(1-10) \mathrm{NH}_{2}$ (5) were confirmed on the basis of NOESY and ROESY as previously reported (4). These intramolecular hydrophobic interactions were also observed clearly in all the other derivatives. NOEs patterns of VIP (1-10) $\mathrm{NH}_{2}$ (5) including sidechains were comparatively similar to those of $\left[\mathrm{A}^{4}, \mathrm{~V}^{5}\right]$-PACAP (1-10) $\mathrm{NH}_{2}$ (8). In addition to the hydrophobic interaction due to aromatic rings, another dipolar through-space connectivities were also confirmed among alkyl groups of sidechains at positions 4 , 5 , and 7 in VIP $(1-10) \mathrm{NH}_{2}(5)$ and $\left[\mathrm{A}^{4}, \mathrm{~V}^{5}\right]$ PACAP (1-10) $\mathrm{NH}_{2}(8)$, and at positions 5 and
7 in PACAP (1-10) $\mathrm{NH}_{2}(6)$ and $\left[\mathrm{G}^{4}, \mathrm{I}^{5}\right]$-VIP (1-10) $\mathrm{NH}_{2}$ (7). NOEs data indicated that PACAP (1-10) $\mathrm{NH}_{2}(6)$ and $\left[\mathrm{G}^{4}, \mathrm{I}^{5}\right]$-VIP (110) $\mathrm{NH}_{2}$ (7) were structurally a little, but a definitely different from VIP $(1-10) \mathrm{NH}_{2}(5)$ and $\left[\mathrm{A}^{4}, \mathrm{~V}^{5}\right]$-PACAP $(1-10) \mathrm{NH}_{2}(\mathbf{8})$ in terms of the indicated hydrophobic interaction, i.e., NOEs data showed interactions between $\mathrm{H}-2$ of His ${ }^{1}$ and aromatic protons of Tyr ${ }^{10}$ of PACAP $(1-10) \mathrm{NH}^{2}$ (6), and between $\mathrm{H}-2$ of $\mathrm{His}^{1}$ and $\gamma$-amide protons of $\mathrm{Asn}^{9}$ of $\left[\mathrm{G}^{4}, \mathrm{I}^{5}\right]$-VIP (1-10) $\mathrm{NH}_{2}$ (7). These interactions indicate the existence of a turn-like structure.

After the assignment of $2 \mathrm{D}-\mathrm{NMR}$, calculations of solution structures were performed using the DISTGEOM program contained in the TINKER molecular modeling package. The used final set of conformational restrains consisted of intramolecular sequential, medium and longrange distances, and of torsional angles estimated by solving Karplus type equations. Diagrams were obtained by the calculation using the distance geometry/simulated annealing protocol (Fig. 8); comparative structural similarities between VIP (1-10) $\mathrm{NH}_{2}$ (5) and $\left[\mathrm{A}^{4}, \mathrm{~V}^{5}\right]$ PACAP (1-10) $\mathrm{NH}_{2}$ (8), and between PACAP

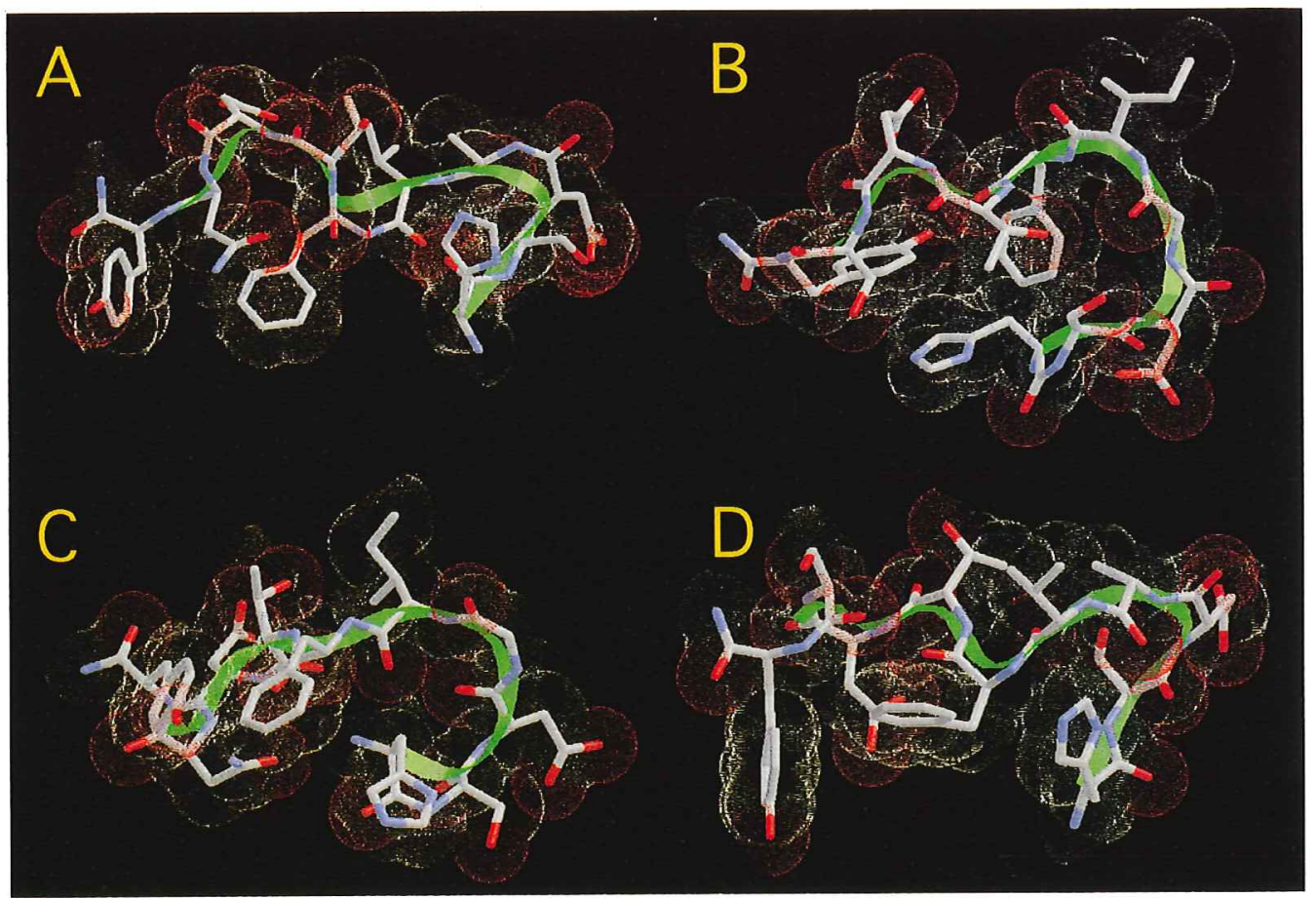

Fig. 8 Refined models with ribbon representation of solution structures of VIP/ PACAP derivatives (A: 5, B: 6, C: 7, D: 8). Overall conformation and Van der Waal' $\mathrm{s}$ dot surface were calculated from simulated annealing and according to the NOEs connectivity data. The C-terminus is toward the left. 
(1-10) $\mathrm{NH}_{2}(6)$ and $\left[\mathrm{G}^{4}, \mathrm{I}^{5}\right]$-VIP (1-10) $\mathrm{NH}_{2}(7)$ were confirmed. These structural similarities were considered to be associated with biological activities.

\section{n-Octanol/Aqueous Partition Coefficient: $\log P$}

The hydropathy scale which denote a sum of hydrophilic and hydrophobic properties of all side-chains of 20 amino acids has been used as an indicator of the polarity of peptides (12). The hydropathy scales of amino acid residues in VIP/ PACAP are shown in Fig. 9.

However, a total sum or the average of these scores does not always represent the actual property of a molecule, because relatively long peptides can take different structures depending on solubilized conditions. Thus, it is quite natural that a sum total of hydrophilicity and hydrophobicity of peptides is changeable.

So we estimated the partition coefficient $\log \mathrm{P}$ that has been used extensively to describe lipophilic or hydrophobic properties of compounds and has been used as a valuable parameter in many QSAR studies that was developed for pharmaceutical, environmental, biochemical, and toxicological sciences.

At first, we investigated the correlation between $\log$ k' obtained by the HPLC method and $\log$ P by the shake-flask method using a lot of reagents. The k'value is defined as follows;

$$
\mathrm{k}^{\prime}=\left(\mathrm{t}_{\mathrm{x}}-\mathrm{t}_{0}\right) / \mathrm{t}_{0}
$$

Where $t_{x}$ is elution times measured with HPLC

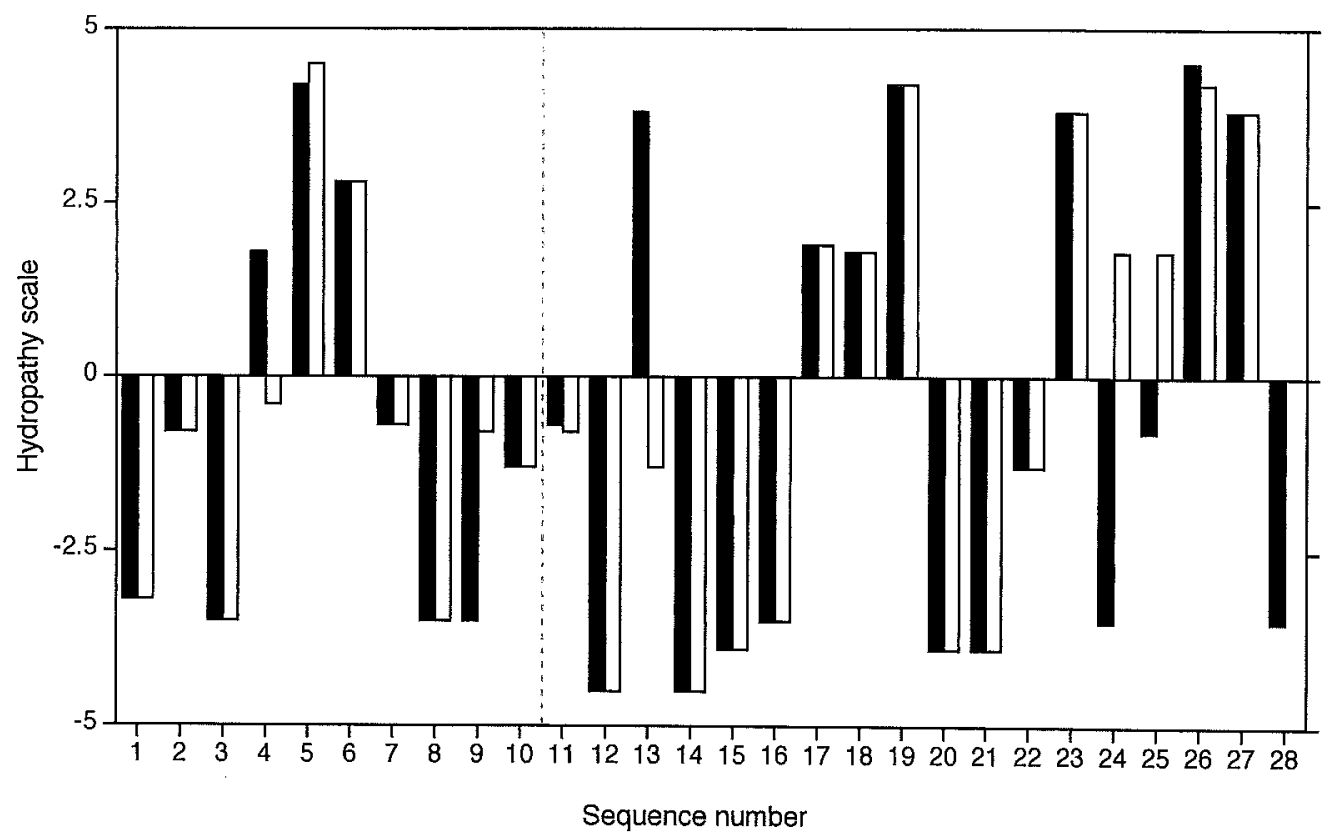

Fig. 9 Individual hydropathy scales for amino acid chains of VIP/PACAP. ( $\square$ ) VIP (1) and ( $\square$ ) PACAP 27 (2).

Table 3 n-Octanol/aqueous partition coefficients for VIP/PACAP derivatives. a, Average $\pm S D(n=3) . b, \log P$ coefficients of peptides determined by interpolation

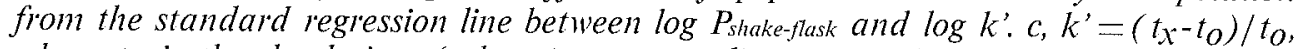
where $t_{o}$ is the dead time (volume) corresponding to $t_{x}$ of formamide and $t_{x}$, the sample time in HPLC.

\begin{tabular}{rcc}
\hline peptide & $\log \mathrm{P}^{\mathrm{a}, \mathrm{b}}$ & $\log \mathrm{K}^{\mathrm{a}, \mathrm{c}}$ \\
\hline VIP $(1-10) \mathrm{NH}_{2}(\mathbf{5})$ & $0.486 \pm 0.005$ & $0.095 \pm 0.002$ \\
PACAP $(1-10) \mathrm{NH}_{2}(\mathbf{6})$ & $1.468 \pm 0.001$ & $0.487 \pm 0.001$ \\
{$\left[\mathrm{G}^{4} \mathrm{I}^{\mathrm{s}}\right]-\mathrm{VIP}(1-10) \mathrm{NH}_{2}(7)$} & $1.376 \pm 0.003$ & $0.450 \pm 0.001$ \\
{$\left[\mathrm{~A}^{4}, \mathrm{~V}^{5}\right]-\mathrm{PACAP}(1-10) \mathrm{NH}_{2}(\mathbf{8})$} & $0.603 \pm 0.002$ & $0.141 \pm 0.001$ \\
\hline
\end{tabular}


and $t_{0}$, the dead volume. On the basis of standard regression line between $\log \mathrm{P}$ and $\log \mathrm{k}, \log \mathrm{P}$ coefficients for VIP/PACAP derivatives (5-8) were determined (Table 3).

\section{Discussion}

It's well known that VIP and PACAP share binding sites categorized into mainly three receptor subtypes in a variety of tissues (22). The first type is PVR 1 which prefers PACAP 38 and PACAP 27 over VIP and which has six variant forms. The second type is PVR 2 which has approximately equally high affinity to PACAP 38, PACAP 27, and VIP and has an alternative nomenclature "Classic" VIP receptors. The third type is PVR 3 which has similar affinities to PACAP 27 and VIP in comparison with PVR 2 and corresponds to the "helodermin-preferring" VIP-binding site.

Although a considerable number of reports on cloning, purification, characterization of the receptors for VIP/PACAP and another peptides belonging to the same family have been published, the relationship of receptor-specificity and their structures in solutions were not investigated in detail. We guessed from reported solution structures that the receptor-binding uniqueness of VIP/PACAP was due to the differences in structures at $\mathrm{N}$-ends. We therefore prepared modified materials $(3,4)$ substituted at positions 4 and 5 that are different sites in the $\mathrm{N}$-terminal sequence of VIP/PACAP.

In the $\left[{ }^{125} I\right]-P A C A P 27$ competitive binding and CAMP accumulation assays using PVR 1$\mathrm{CHO}$, an interesting tendency was found, i.e., biological activities of $\left[\mathrm{G}^{4}, \mathrm{I}^{5}\right]$-VIP (3) was clearly increased as compared with its native compound VIP (1), and, by contrast, those of $\left[\mathrm{A}^{4}, \mathrm{~V}^{5}\right]$-PACAP (4) was decreased as comparcd with PACAP (2). This result indicates that the residues at 4 and 5 are important for bindingspecificity. This was also supported by the results that the binding activities of VIP/PACAP derivatives were associated with cAMP accumulation in PVR 1-CHO and PVR 2-CHO cells.

A peptide containing Gly is generally thought to be as flexible as one containing Pro. Although the flexibility of Pro is mostly depending on its sis-, and trans-tautomerism, that of Gly is undoubtedly due to no steric hindrance allowed by its minimum sidechain. Of all known elements of peptide conformation, the turn structure is one of the most frequent. Usually, Gly or Pro is present in the center of a turn moiety as a bending component.

To obtain detailed information on peptide structures, we evaluated some physical properties in detail. CD data (Fig. 5) indicated that have little effects on helical conformations even if residues at 4 and 5 were substituted, because significant changes in helix contents were not detected between native and substituted peptides. Therefore, we supposed that the biological alterations of VIP/PACAP after N-terminal modifications were not affected by $\alpha$-helix structures but merely affected by the disordered $\mathrm{N}$-terminal structures.

So we investigated the solution structures of a series of another synthesized derivatives (5-8) focussing on $\mathrm{N}$-terminal structures with the presumption that the critical sites for a specific receptor must reside in the N-terminals. Nterminal solution structures obtained by NMR spectral analyses are refined further by simulated annealing/distance geometry calculation as shown in Fig. 8. The structure of a Glycontaining peptide PACAP (1-10) $\mathrm{NH}_{2}(6)$ is comparatively similar to that of $\left[\mathrm{G}^{4}, \mathrm{I}^{5}\right]$-VIP (110) $\mathrm{NH}_{2}$ (7). The structure of VIP $(1-10) \mathrm{NH}_{2}$ (5) is also similar to that of $\left[\mathrm{A}^{4}, \mathrm{~V}^{5}\right]$-PACAP $(1-$ 10) $\mathrm{NH}_{2}$ (8). Particularly, PACAP (1-10) $\mathrm{NH}_{2}$ (6) and $\left[\mathrm{G}^{4}, \mathrm{I}^{5}\right]$-VIP $(1-10) \mathrm{NH}_{2}$ (7) have a folding or turn-like structure. In addition, we evaluated the hydrophilic and hydrophobic properties of each $\mathrm{N}$-terminal fragment to confirm whether the receptor-binding specificity of VIP/ PACAP also depends on their N-terminal polarity or not. Because a lot of physical characters such as covalent bonds, hydrogen bonds, hydrophobic interaction, and electrostatic interactions are known as interactive factors concerning ligand and receptor binding, and the polarity was somewhat related to these components. On hydropathy scale of VIP/PACAP (Fig. 9), the average scores are estimated to be -0.8 for VIP $(1-10) \mathrm{NH}_{2}(5),-0.7$ for PACAP $(1-10) \mathrm{NH}_{2}$ (6), -1.0 for $\left[\mathrm{G}^{4}, \mathrm{I}^{5}\right]$-VIP $(1-10) \mathrm{NH}_{2}(7)$, and 0.6 for $\left[\mathrm{A}^{4}, \mathrm{~V}^{5}\right]$-PACAP $(1-10) \mathrm{NH}_{2}(8)$.

Although no correlation between average hydropathy scores and structures was seen, the $n$-octanol/aqueous partition coefficient $\log \mathrm{P}$ provides the following relationship: 1) Lower log $\mathrm{P}$ values were tended to belong to hydrophilic materials. 2) The $\log \mathrm{P}$ value of VIP $(1-10) \mathrm{NH}_{2}$ (5) is close to that of $\left[\mathrm{A}^{4}, \mathrm{~V}^{5}\right]-\mathrm{PACAP}(1-$ 
10) $\mathrm{NH}_{2}$ (8). 3) The log P values of PACAP (110) $\mathrm{NH}_{2}(6)$ and $\left[\mathrm{G}^{4}, \mathrm{I}^{5}\right]$-VIP $(1-10) \mathrm{NH}_{2}(7)$ are similar each other. These results were relatively consistent with presumed structural similarities examined by NMR spectral analyses and distance geometry calculation based on NMR data.

From these structure-activity relationship, we concluded that N-terminal structures play an important role in the binding-specificity of VIP/ PACAP to their receptors. In particular, $\left[\mathrm{A}^{4}, \mathrm{~V}^{5}\right]$ in VIP and $\left[\mathrm{G}^{4}, \mathrm{I}^{5}\right]$ in PACAP 27 are indispensable for their specificities.

\section{Acknowledgments}

The authors are grateful to Prof. Noboru Yanaihara, Yanaihara Institute Inc. for his valuable discussion, and to Dr. Yohko Ohshima of the Toho University for NMR measurements. We also thank the TINKER molecular modeling package provided at the following web site: http://dasher.wustle.edu (128.252.162.151).

\section{REFERENCES}

1. Balacco G., (1996) A desktop calculation for the Karplus equation. J. Chem. Inf. Comput. Sci. 36, 885-887.

2. Fry D. C., Madison V. S., Bolin D. R., Greeley D. N., Toome V., and Wegrzynski B. B. (1989) Solution structure of an analogue of vasoactive intestinal peptide as determined by two-dimensional NMR and circular dichroism spectroscopies and constrained molecular dynamics. Biochemistry 28, 2399-2409.

3. Fujita T., Iwasa J., and Hansch C. (1964) A new substituent constant, $\pi$, derived from partition coefficients. $J$. Am. Chem. Soc. 86, 5175-5179.

4. Goossens J. F., Cotelle P., Chavatte P., and Henichart J. P. (1996) NMR study of five $\mathrm{N}$-terminal peptide fragments of the vasoactive intestinal peptide: crucial role of aromatic residues. Pept. Res. 9, 322-326.

5. Gottschall P. E, Tatsuno I., Miyata A., and Arimura A. (1990) Characterization and distribution of binding sites for the hypothalamic peptide, pituitary adenylate cyclase activating polypeptide. Endocrinology. 127, 272-277.

6. Gourlet P., Vandermeers A., Van Rampelbergh J., De Neef P., Cnudde J., Waelbroeck M., and Robberecht P. (1998) Analogues of VIP, helodermin, and PACAP discriminate between rat and human VIP 1 and VIP 2 receptors. $A n n$. N. Y. Acad. Sci. 865, 247-252.

7. Greenfield N., and Fasman G. D. (1969) Computed circular dichroism spectra for the evaluation of protein conformation. Biochemistry 8, 4108-4116.

8. Hata F., and Takeuchi T. (1997) Inhibitory neuronal control of smooth muscle activity of the gastrointestinal tract. Nippon Yakugaku Zasshi 109, 61-73.

9. Hodsdon M. E., Ponder J. W., and Cistola D. P. (1996) The NMR solution structure of intestinal fatty acidbinding protein complexed with palmitate: application of a novel distance geometry algorithm. J. Mol. Biol. 264,
$585-602$

10. Inooka H., Endo S., Kitada C., Mizuta E., and Fujino M. (1992) Pituitary adenylate cyclase activating polypeptide (PACAP) with 27 residues. Int. J. Peptide Protein Res. 40, 456-464.

11. Karplus M., (1963) Vicinal proton coupling in nuclear magnetic resonance. J. Am. Chem. Soc. 85, 2870-2871.

12. Kyte J., and Doolittle R. F. (1982) A simple method for displaying the hydropathic character of a protein. J. Mol. Biol. 157, 105-132.

13. Matsuzaki Y., Hamasaki Y., and Said S. I. (1980) Vasoactive intestinal peptide: a possible transmitter of nonadrenergic relaxation of guinea pig airways. Science 210, 1252-1253.

14. Miyata A., Arimura A., Dahl R. R., Minamino N., Uehara A., Jiang L., Culler M. D., and Coy D. H. (1989) Isolation of a novel 38 residue-hypothalamic polypeptide which stimulates adenylate cyclase in pituitary cells. Biochem. Biophys. Res. Conmun. 164, 567-574.

15. Miyata A., Jiang L., Dahl R. R., Kitada C., Kubo K., Fujino M., Minamino N., and Arimura A (1990) Isolation of a neuropeptide corresponding to the N-terminal 27 residues of the pituitary adenylate cyclase activating polypeptide with 38 residues (PACAP), Biochem. Biophys. Res. Commun. 170, 643-648.

16. Miyata A., Sato K., Hino J., Tamakawa H., Matsuo H., and Kangawa K. (1998) Rat aortic smooth-muscle cell proliferation is bidirectionally regulated in a cell cycledependent manner via PACAP/VIP type 2 receptor. $A n n$. N. Y. Acad. Sci. 865, 73-81.

17. Motomura Y., Chijiiwa Y., Iwakiri Y., Ochiai T., and Nawata H. (1998) Interactive mechanisms among pituitary adenylate cyclase-activating peptide, vasoactive intestinal peptide, and parathyroid hormone receptors in guinea pig cecal circular smooth muscle cells. Endocrinology 139, 2869-78.

18. Nokihara K., Ando E., Naruse S., Nakamura T., and Wray V. (1993) Highly efficient synthesis of PACAP and its related peptides and their biological actions in conscious dogs. Peptide Chemistry 1993, 265-268.

19. Nussdorfer G. G., and Malendowicz L. K. (1998) Role of VIP, PACAP, and related peptides in the regulation of the hypothalamo-pituitary-adrenal axis. Peptides 19, 14431467.

20. Ohtaki T., Masuda Y., Ishibashi Y., Kitada C., Arimura A., and Fujino M. (1993) Purification and characterization of the receptor for pituitary adenylate cyclaseactivating polypeptide. J. Biol. Chem. 35, 26650-26657.

21. Pardi A., Billeter M., and Wüthrich K., (1984) Calibration of the angular dependence of the amide proton- $\mathrm{C}^{\alpha}$ proton coupling constants, ${ }^{3} J_{\mathrm{HN} \alpha}$, in a globular protein. J. Mol. Biol. 180, 741-751.

22. Rawlings S. R., and Hezareh M. (1996) Pituitary adenylate cyclase-activating polypeptide (PACAP) and PACAP/ Vasoactive Intestinal Polypaptide receptors: actions on the anterior pituitary gland. Endocrine Reviews 17, 4-29.

23. Robberecht P., Woussen-Colle M. C., De Neef P., Bourlet P., Buscail L., Vandermeers A., Vandermeers Piret M.C., and Christophe J. (1991) The two forms of the pituitary adenylate cyclase activating polypeptide (PACAP (1-27) and PACAP (1-38)) interact with distinct receptors on rat pancreatic AR 4-2 J cell membranes. FEBS Lett. 286, 133-136.

24. Said S. I., and Mutt V. (1970) Polypeptide with broad 
biological activity: isolation from the small intestine. Science 69, 1217-1218.

25. Shivers B. D., Gorcs T. J., Gottschall P. E., and Arimura A. (1991) Two high-affinity binding sites for pituitary adenylate cyclase activating polypeptide have different tissue distributions. Endocrinology 128, 3055-3065.

26. Tatsuno I., Gottschall P. E., and Arimura A. (1991) Specific binding sites for pituitary adenylate cyclase activating polypeptide (PACAP) in rat cultured astrocytes: molecular identification and interaction with vasoactive intestinal peptide (VIP). Peptides 12, 617-621.

27. Uchida D., Tatsuno I., Tanaka T., Hirai A., Saito Y., Moro O., and Tajima M. (1998) Maxadilan is a specific agonist and its deleted peptide (M 65) is a specific antagonist for PACAP type 1 receptor. Ann. N. Y. Acad. Sci. $\mathbf{8 6 5}, 253-258$.

28. Unger S. H., Cook J. R., and Hollenberg J. S. (1978) Simple procedure for determining octanol-aqueous parti- tion, distribution, and ionization coefficients by reversedphase high-pressure chromatography. J. Pharm. Sci. 67, 1364-1367.

29. Watanabe T., Ohtaki T., Kitada G., Tsuda M., and Fujino M. (1990) Adrenal pheochromocytoma PC $12 \mathrm{~h}$ cells respond to pituitary adenylate cyclase activating polypeptide. Biochem. Biophys. Res. Commun. 173, 252-258.

30. Wider G., Macura S., Kumar A., Ernst R. R., and Wüthrich K. (1984) Homonuclear two-dimensional 'H NMR of proteins. experimental procedures. J. Magn. Reson. 56, 207-234

31. Wray V., Kakoschke C., Nokihara K., and Naruse S. (1993) Solution structure of pituitary adenylate cyclase activating polypeptide by nuclear magnetic resonance spectroscopy. Biochemistry 32, 5832-5841.

32. Wüthrich K. (1986) "NMR of Proteins and Nucleic Acids" Wiley-Interscience, New York. 